DOI: https://doi.org/10.24144/2409-6857.2018.1(51).393-400

УДК 338.48:336.14:352

Шот А.П.

\title{
АНАЛІЗ ВПЛИВУ ДІЯЛЬНОСТІ ТУРИСТИЧНОГО БІЗНЕСУ НА ДОХОДИ МІСЦЕВИХ БЮДЖЕТІВ
}

\begin{abstract}
У статті розглянуто тенденції розвитку туристичного бізнесу в Україні та регіонах, проведено аналіз туристичних потоків та мотивачії туристичних поӥздок, визначено мережу суб'єктів туристичної бізнесу та причини коливання їх кількості. Здійснено аналіз діяльності та дана оцінка податкових надходжень до бюджету від суб'єктів туристичної галузі. Проведено порівняння вкладу туристичної галузі у розвиток світової та вітчизняної економіки. Обгрунтовано необхідність прискореного розвитку та впливу галузі на економіку країни та регіонів, розроблено модель формування туристичної індустрії.
\end{abstract}

Ключові слова: туристичний збір, податкові платежі, місцеві бюджети, туристичний бізнес, туристична галузь, турагенти, туроператори, туристичні потоки, аналіз.

Постановка проблеми. Туристична галузь $\epsilon$ важливим чинником розвитку економіки та соціального розвитку країни, зміцнення позитивного іміджу України у світі, пожвавлення міжнародної співпраці, збільшення валютних надходжень, підвищення рівня зайнятості населення, зменшення безробіття та ін. Туризм є однією 3 найбільш перспективних галузей світової економіки. Крім цього, він для 40\% країн - головне, а для близько $80 \%$ є одним 3 п'яти основних джерел доходу [1].

Слід зазначити, що Україна, маючи величезний потенціал (зручне географічне розташування, сприятливий клімат, різноманітний рельєф), суттєво відстає від світових лідерів, посідаючи лише 20 місце серед країн світу 3 отримання сукупного річного доходу від провадження туристичної діяльності. Частка туристичної галузі у структурі ВВП України за різними оцінками складає від 1\% до $5 \%$ (середньосвітовий рівень близько 9\%). Так, наприклад в Австрії частка туристичного бізнесу у ВВП складає $-8 \%$, в Хорватії $-8,5 \%$, в Іспанії $-6,8 \%$.

Дослідження показали, що якщо валютні надходження країни щорічно зростають на $10 \%$, то туризм випередив експорт нафтопродуктів, телекомунікаційного обладнання, автомобілебудування. Сфера туризму в Україні формує лише $6 \%$ експортних доходів держави, в той час як в Іспанії - 35\%, Греції - 36\%, на Кіпрі $-52 \%$ [2].

Якщо у 2014 р. в туризмі було зайнято 1,27 млн осіб $(6,4 \%$ загальної кількості працівників), то у 2015 p. цей показник

(C) Шот Анна Петрівна, к.е.н., доц., доцент кафедри обліку і аудиту факультету управління фінансами та бізнесу, ЛНУ ім. Івана Франка, м. Львів, тел.: 0676899364, email: annashot111@gmail.com збільшився до 1,29 млн осіб, тобто на 1,3\% (6,5\% загальної кількості працівників). За прогнозами Всесвітньої ради 3 подорожей і туризму, до 2025 р. цей показник зменшиться на 1,0\% (6,0\% загальної кількості зайнятості). Як показало дослідження, ці показники значно нижчі за аналогічні показники інших держав ЦентральноСхідної Європи [3].

Отже, туристичний потенціал України на сьогодні розкрито недостатньо, що негативно впливає на надходження до бюджету податків та зборів від провадження туристичної діяльності. У зв'язку 3 дефіцитом бюджету, проблема збільшення бюджетних надходжень до місцевих бюджетів, у тому числі i за рахунок туристичного збору, набуває особливого значення, $\epsilon$ актуальною і потребує дослідження.

Аналіз останніх досліджень і публікацій. Дослідженням проблем розвитку туристичного бізнесу в Україні присвячені численні публікації вітчизняних науковців та практиків, серед яких: Кузишин А.В. (туристична активність та дохідність в європейських країнах), Січка I.I. (вплив туристичної сфери на економіку країни), Папп В.В. (роль готельного бізнесу у розвитку туризму), Луцька Н.I., Криховський I.3., (чинники розвитку туризму), Жук І.З. (необхідність реформування туристичної сфери), Кравців В.С. (перспективи розвитку вітчизняного та світового туризму), Ткаченко Т.I. (ринковий механізм управління туризмом та його суб'єктами), Ястремська О.О. (тенденції розвитку туризму) та інші. Проте на сьогодні актуальною та не достатньо дослідженою $\epsilon$ проблема наповнення місцевих бюджетів та збільшення податкових надходжень від туристичного бізнесу в Україні.

Формулювання цілей статті. Метою дослідження $\epsilon$ визначити тенденції розвитку туристичного бізнесу в Україні, проаналізувати 
податкові надходження від суб' єктів туристичної галузі, обгрунтувати необхідність прискореного розвитку та впливу галузі на економіку країни, розробка пропозицій щодо створення повноцінної туристичної індустрії.

Опис основного матеріалу дослідження. Сучасні глобальні виклики та складнощі реформування національної економіки зумовлюють потребу пошуку нових можливостей для розвитку країни та регіонів. Часи сподівання винятково на зовнішні фінансові ресурси відходять в минуле, а визначального значення набуває ефективність використання власного соціально-економічного потенціалу. I сьогодні туристичний бізнес повинен розглядатися як одне $з$ основних потенційних джерел доходу як державного, так і місцевих бюджетів.

Адже в умовах значного дефіциту державного бюджету в Україні доходи від туризму могли б сприяти соціально-економічному розвитку

Таблиця 1

Динаміка відвідування України іноземними туристами за 2010-2016 рр.*

\begin{tabular}{|l|c|c|c|c|c|c|c|c|c|}
\hline \multicolumn{1}{|c|}{ Показник } & $\mathbf{2 0 1 0}$ & $\mathbf{2 0 1 1}$ & $\mathbf{2 0 1 2}$ & $\mathbf{2 0 1 3}$ & $\mathbf{2 0 1 4}$ & $\mathbf{2 0 1 5}$ & $\mathbf{2 0 1 6}$ \\
\cline { 2 - 8 } & \multicolumn{7}{|c|}{ роки } \\
\hline $\begin{array}{l}\text { Іноземні туристи, які в"їхали до } \\
\text { України, млн осіб }\end{array}$ & 23,5 & 23,9 & 24,6 & 25,7 & 13,0 & 12,9 & 13,6 \\
\hline $\begin{array}{l}\text { Темпи зростання (спаду +,-), } \\
\text { млн осіб }\end{array}$ & - & $+0,4$ & $+0,7$ & $+1,1$ & $-12,7$ & $-0,1$ & $+0,7$ \\
\hline
\end{tabular}

*Розраховано автором за даними [4]

Збільшення доходів від туристичного бізнесу у великій мірі залежить від кількості туристів, які відвідують Україну. Проведене дослідження свідчить, що з початком військових дій на Сході України кількість іноземних туристів скоротилась майже у двічі, проте за останні роки спостерігається тенденція до зростання. Так у 2016 році до України в'їхало 13,6 млн туристів, що на 5,6 \% більше, ніж у 2015 році. При цьому у 2015 році у порівнянні із 2014 роком в”іхало на 0,2 млн осіб (або 1,3\%) менше (табл.1).

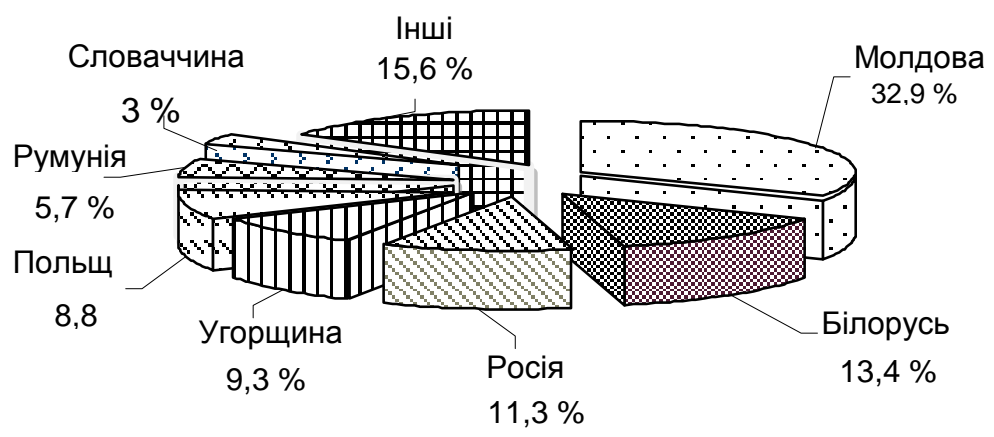

Рис. 1. Розподіл за країнами чисельності іноземних громадян, які відвідали Україну у 2016 році [4]

Розподіл за країнами чисельності іноземних громадян, які відвідали Україну у 2016 році та приріст (спад) порівняно 32015 роком наступний: Молдова - 32,9\% (-5,6\%), Білорусь -
$13,4 \%$ (-3,7\%), Росія $-11,3 \%$ (+16,8\%), Угорщина $-9,3 \%(+18,6 \%)$, Польща - 8,8\% (+3,3\%), Румунія - 5,7\% (+1,4\%), Словаччина - $3 \%(-0,6 \%)$ та інші країни $(15,6 \%)$ (рис. 1 , табл. 2$)$.

Динаміка структури ТОП 20 країн світу, громадяни яких відвідали

Таблиця 2

Україну в 2014 - 2016 роках *

\begin{tabular}{|c|c|c|c|c|c|c|}
\hline \multirow{2}{*}{ Назва країни } & \multirow{2}{*}{2014 p. } & \multirow{2}{*}{2015 p. } & \multirow{2}{*}{2016 p. } & \multirow{2}{*}{ Частка, \% } & \multicolumn{2}{|c|}{ Приріст 2016/2015 } \\
\hline & & & & & ociб & $\%$, рази \\
\hline 1. Молдова & 4587265 & 4739590 & 4474151 & 32,9 & 265439 & $\downarrow 5,6 \%$ \\
\hline 2. Білорусь & 1606094 & 1898539 & 1827751 & 13,4 & $\begin{array}{l}-70788 \\
\end{array}$ & $\downarrow 3,7 \%$ \\
\hline 3. Росія & 2438335 & 1320988 & 1542631 & 11,3 & 221643 & $\uparrow 16,8 \%$ \\
\hline 4. Угорщина & 877378 & 1072080 & 1271173 & 9,3 & 199093 & $\uparrow 18,6 \%$ \\
\hline 5. Польща & 1132078 & 1156907 & 1195089 & 8,8 & 38182 & $\uparrow 3,3 \%$ \\
\hline
\end{tabular}




\begin{tabular}{|c|c|c|c|c|c|c|}
\hline & & & & & \multicolumn{2}{|c|}{ Продовження табл.2 } \\
\hline 6. Румунія & 585019 & 765010 & 775823 & 5,7 & 10813 & $\uparrow 1,4 \%$ \\
\hline 7. Словаччина & 417401 & 413176 & 410732 & 3,0 & -2444 & $\downarrow 0,6 \%$ \\
\hline 8. Ізраїль & 101919 & 149620 & 217160 & 1,6 & 67540 & $\uparrow 45,1 \%$ \\
\hline 9. Туреччина & 120490 & 142883 & 206706 & 1,5 & 63823 & $\uparrow 44,7 \%$ \\
\hline 10. Німеччина & 132687 & 155768 & 171455 & 1,3 & 15687 & $\uparrow 10,1 \%$ \\
\hline 11. Таджикистан & 37323 & 54001 & 165158 & 1,2 & 111157 & $\uparrow 3$ рази \\
\hline 12. США & 81838 & 108492 & 138202 & 1,0 & 29710 & $\uparrow 27,4 \%$ \\
\hline 13. Узбекистан & 159012 & 68823 & 136021 & 1,0 & 67198 & $\uparrow 1,9$ рази \\
\hline 14. Азербайджан & 69776 & 75777 & 105874 & 0,8 & 30097 & $\uparrow 39,7 \%$ \\
\hline 15. Італія & 55412 & 63305 & 77840 & 0,6 & 14535 & $\uparrow 23 \%$ \\
\hline 16. Великобританія & 44244 & 54835 & 70414 & 0,5 & 15579 & $\uparrow 28,4 \%$ \\
\hline 17. Франція & 39944 & 45999 & 54280 & 0,4 & 8281 & $\uparrow 18 \%$ \\
\hline 18. Литва & 30928 & 35308 & 52273 & 0,4 & 16965 & $\uparrow 48 \%$ \\
\hline 19. Чехія & 35281 & 39501 & 49051 & 0,4 & 9550 & $\uparrow 24,2 \%$ \\
\hline 20. Грузія & 35022 & 37849 & 48414 & 0,4 & 10565 & $\uparrow 27,9 \%$ \\
\hline Всього & 13049138 & 12886231 & 13605916 & 100,0 & 719685 & $\uparrow 5,6 \%$ \\
\hline
\end{tabular}

*Розраховано автором за даними [4]

Аналіз мотивації туристичних поїздок (ділова, приватна, туристична, навчання, службова, релігійна тощо) іноземних громадян до України у 2014 - 2016 роках показав, що найбільшу частку серед усіх видів поїздок складають приватні. Відсоток приватних поїздок іноземних туристів в Україну за досліджуваний період коливається в межах від 74,3\% у 2014 р. до 95,3\% у 2016p., частка туризму від 1,1\% до 1,3\%.

Найбільший приріст серед мотивацій поїздок у 2016 р. порівняно 32015 p. спостерігається за такими видами як туризм $(+25 \%)$, приватні поїздки $(+12,5 \%)$ та навчання $(+20,7 \%)$ (табл.3).

Таблиця 3

Аналіз динаміки та структури мотивації туристичних поїздок іноземних громадян до України у $2014-2016$ роках*

\begin{tabular}{|c|c|c|c|c|c|c|c|}
\hline \multirow{2}{*}{$\begin{array}{c}\text { Мета } \\
\text { поїздки }\end{array}$} & \multicolumn{2}{|c|}{2014 p. } & \multicolumn{2}{|c|}{2015 p. } & \multicolumn{2}{|c|}{2016 p. } & \multirow{2}{*}{$\begin{array}{c}\text { Приріст } \\
\text { (спад, } \uparrow \downarrow) \\
2016 / 2015\end{array}$} \\
\hline & Ociб & Частка, \% & Осіб & Частка, \% & Ociб & Частка, \% & \\
\hline службова & 46085 & 0,4 & 40479 & 0,3 & 33007 & 0,2 & $\downarrow 18,5 \%$ \\
\hline ділова & 2556 & 0,0 & 615 & 0,0 & 195 & 0,0 & $\downarrow 3,2$ рази \\
\hline туризм & 146804 & 1,1 & 137906 & 1,1 & 172848 & 1,3 & $\uparrow 25,3 \%$ \\
\hline приватна & 9696854 & 74,3 & 11525239 & 89,4 & 12963324 & 95,3 & $\uparrow 12,5 \%$ \\
\hline навчання & 1109 & 0,0 & 101 & 0,0 & 2087 & 0,0 & $\uparrow 20,7$ рази \\
\hline релігійна & 1942 & 0,0 & 5431 & 0,0 & 5501 & 0,0 & $\uparrow 1,3 \%$ \\
\hline $\begin{array}{l}\text { культурний } \\
\text { та спортивний } \\
\text { обмін }\end{array}$ & 494 & 0,0 & 17 & 0,0 & 6108 & 0,0 & $\uparrow 359,3$ рази \\
\hline транзит & 341709 & 2,6 & 461638 & 3,6 & 266564 & 2,0 & $42,3 \%$ \\
\hline інша & 2811585 & 21,5 & 714805 & 5,5 & 156282 & 1,1 & $\downarrow 4,6$ рази \\
\hline Всього: & 13049138 & 100 & 12886231 & 100 & 13605916 & 100 & $\uparrow 5,6 \%$ \\
\hline
\end{tabular}

*Розраховано автором за даними [4]

Отже туризм на сьогодні для більшості іноземних громадян не $\epsilon$ основною метою поїздки в Україну. Проведене дослідження показало, що у число світових лідерів за кількістю прибуттів (у 2007-2016 рр.) входили такі держави, як Франція, Іспанія, Італія, Туреччина, Німеччина, Велика Британія, Російська Федерація, Австрія. До 2013 р. такі ж лідируючі позиції займала i Україна 3 показником понад 20 млн туристичних прибуттів, але військові дії на Сході держави привели до різкого скорочення інтересу до країни - майже в два рази зменшився показник прибуттів - до 12,8 млн в 2015 р. [5].

Враховуючи вищевказане, за державної підтримки та при наявності і реалізації Стратегії сталого розвитку «Україна-2020» та Державної стратегії регіонального розвитку України, туризм 
може сприяти вирішенню проблем забезпечення регіонів, територіальних громад фінансовими ресурсами. Одним 3 iз таких джерел $\epsilon$ туристичний збір.

Відповідно до ст. 268 ПКУ туристичний збір це місцевий збір, кошти від якого зараховуються до місцевого бюджету. Туристичний збір, як відомо, утримується при наданні послуг 3 тимчасового проживання (ночівлі), iз зобов'язанням залишити місце перебування в зазначений строк з громадян України, іноземців, а також осіб без громадянства, які прибувають на територію адміністративно-територіальної одиниці, на якій діє рішення сільської, селищної та міської ради про встановлення туристичного збору. Ставка встановлюється у розмірі від 0,5\% до $1 \%$ до бази справляння збору. Базою справляння $\epsilon$ вартість усього періоду проживання (ночівлі), за вирахуванням податку на додану вартість [6].

Проведене дослідження показало, що обсяг надходжень до місцевих бюджетів від сплати туристичного збору за 2014-2016 роки збільшився більше ніж у 2 рази 324766,7 тис. грн у 2014 р. до 54094,8 тис. грн у 2016 р. Обсяг надходжень від сплати туристичного збору до місцевих бюджетів у 2016 році склав 54,1 млн. грн., що на 45,7 \% більше ніж у 2015 році. (у 2015 р. порівняно з 2014 р. зростання на 49,9\%).

До 5 областей України за найбільшими обсягами надходжень від сплати туристичного збору, що надійшли до місцевих бюджетів у 2016 р., входили: м. Київ - 18,8 млн грн (34,7 \%), Львівська обл. - 8,4 млн грн (15,6\%), Одеська обл. - 7,3 млн грн $(13,6 \%)$, Івано-Франківська обл. - 2,3 млн грн (4,2\%), Закарпатська обл. 2,2 млн грн $(4,1 \%)$ [7].

Серед лідерів за найбільшим зростанням обсягу туристичного збору до місцевих бюджетів у 2016 р. порівняно 3 попереднім роком були 5 областей України : м. Київ - на 4,9 млн грн.(на $50,1 \%$ ), Львівська обл. - на 2,5 млн грн (на $42,3 \%$ ), Одеська обл. - на 2,5 млн грн (на $50,8 \%$ ), Херсонська обл. - на 0,8 млн грн (на $75,7 \%)$, Івано-Франківська обл. - на 0,7 млн грн (на 45,3\%). (табл. 4, рис.3). Якщо аналізувати податкові надходження одного 35 лідерів Львівську область, то слід відмітити, що за останні 10 років, в цілому вони зросли у 3,22 рази, у тому числі за рахунок місцевих податків i зборів у 20,06 рази, податку на доходи фізичних осіб у 3,35 рази, за рахунок туристичного збору аж у 46,02 раз [7].

\section{Динаміка надходження туристичного збору до місцевих бюджетів}

Таблиця 4 за 2014-2016 роки, * тис. грн

\begin{tabular}{|c|c|c|c|c|c|c|}
\hline $\begin{array}{c}\text { Код } \\
\text { регіону }\end{array}$ & Назва області & 2014 p. & 2015 p. & 2016 p. & Частка, \% & Приріст $\uparrow)$, 2016/2015 \\
\hline 1 & АР Крим & 482,6 & 0 & - & - & - \\
\hline 2 & Вінницька & 181,1 & 209,6 & 310,4 & 0,6 & $\uparrow 48,1 \%$ \\
\hline 3 & Волинська & 200,7 & 324,2 & 373,4 & 0,7 & $\uparrow 15,2 \%$ \\
\hline 4 & Дніпропетровська & 877,4 & 1289,4 & 1749,9 & 3,2 & $\uparrow 35,7 \%$ \\
\hline 5 & Донецька & 846,1 & 669,1 & 914,3 & 1,7 & $\uparrow 36,6 \%$ \\
\hline 6 & Житомирська & 169,0 & 225,3 & 349,4 & 0,6 & $\uparrow 55,1 \%$ \\
\hline 7 & Закарпатська & 930,4 & 1527,2 & 2199,1 & 4,1 & $\uparrow 44,0 \%$ \\
\hline 8 & Запорізька & 1410,8 & 1565,3 & 2070,8 & 3,8 & $\uparrow 32,3 \%$ \\
\hline 9 & Івано-Франківська & 946,8 & 1578,5 & 2292,8 & 4,2 & $\uparrow 45,3 \%$ \\
\hline 10 & Київська & 682,4 & 862,5 & 1247,9 & 2,3 & $\uparrow 44,7 \%$ \\
\hline 11 & Кіровоградська & 65,7 & 92,3 & 167,9 & 0,3 & $\uparrow 1,8$ рази \\
\hline 12 & Луганська & 109,4 & 47,7 & 102,7 & 0,2 & $\uparrow 2,1$ рази \\
\hline 13 & Львівська & 3569,8 & 5915,0 & 8418,5 & 15,6 & $\uparrow 42,3 \%$ \\
\hline 14 & Миколаївська & 457,5 & 753,1 & 1155,3 & 2,1 & $\uparrow 53,4 \%$ \\
\hline 15 & Одеська & 2725,3 & 4865,2 & 7336,3 & 13,6 & $\uparrow 50,8 \%$ \\
\hline 16 & Полтавська & 313,4 & 449,2 & 717,1 & 1,3 & $\uparrow 59,7 \%$ \\
\hline 17 & Рівненська & 127,2 & 170,2 & 266,5 & 0,5 & $\uparrow 56,6 \%$ \\
\hline 18 & Сумська & 130,5 & 161,6 & 227,6 & 0,4 & $\uparrow 40,8 \%$ \\
\hline 19 & Тернопільська & 128,7 & 161,4 & 240,0 & 0,4 & $\uparrow 48,7 \%$ \\
\hline 20 & Харківська & 887,8 & 1081,5 & 1780,5 & 3,3 & $\uparrow 64,6 \%$ \\
\hline 21 & Херсонська & 793,2 & 1074,7 & 1888,4 & 3,5 & $\uparrow 75,7 \%$ \\
\hline 22 & Хмельницька & 207,8 & 303,1 & 465,7 & 0,9 & $\uparrow 53,7 \%$ \\
\hline 23 & Черкаська & 271,1 & 310,9 & 409,5 & 0,8 & $\uparrow 31,7 \%$ \\
\hline
\end{tabular}




\begin{tabular}{|c|l|c|c|c|c|c|}
\hline \multicolumn{1}{|c|}{ Продовження табл.4 } \\
\hline 24 & Чернівецька & 228,2 & 244,1 & 318,6 & 0,6 & $\uparrow 30,5 \%$ \\
\hline 26 & Чернігівська & 154,8 & 207,8 & 311,9 & 0,6 & $\uparrow 50,1 \%$ \\
\hline 27 & м. Київ & 5788,0 & 9779,0 & 14706,6 & 27,2 & $\uparrow 50,4 \%$ \\
\hline 28 & Центрастополь & 58,5 & 0 & - & - & - \\
\hline & Всього & 2022,6 & 3257,9 & 4073,6 & 7,5 & $\uparrow 25,0 \%$ \\
\hline
\end{tabular}

*Розраховано автором за даними [7]

Туристична привабливість $є$ однією важливих цілей Стратегії розвитку Львівщини, що визначається значним туристично-рекреаційним потенціалом регіону, яка має на меті підвищення ефективності використання туристичнорекреаційного потенціалу регіону та формування повноцінної туристичної індустрії.
У Львівському регіоні з 2005 року нішу туристичного бізнесу все більше займає приватний сектор, про що демонструють показники кількості готельних закладів, які $є$ у власності фізичних осіб, а також зростання відрахувань до бюджету підприємцями, які діють у туристично-рекреаційній сфері.

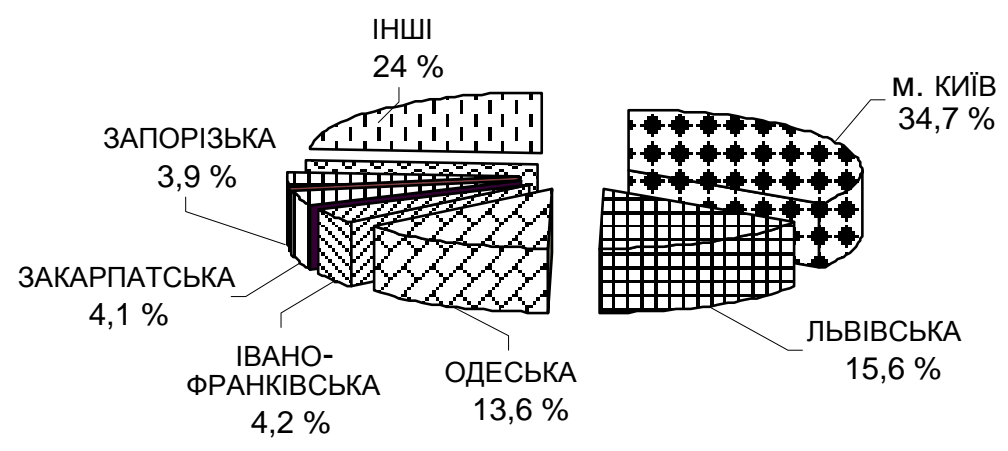

Рис. 3. Питома вага туристичного збору у загальному обсязі надходжень відповідних місцевих бюджетів за 2016 рік, у розрізі областей [7]

Разом 3 тим бюджетонаповнююча роль туристично-рекреаційної сфери в області лишається низькою. Однією $з$ причин цього $є \mathrm{i}$ тіньова зайнятість, наслідком якої $\epsilon$ недонадходження коштів до бюджету [8]. Така тенденція спостерігається і в цілому по Україні.
Порівняльний аналіз надходжень податкових платежів за КВЕД та видами платників свідчить, що в цілому по Україні темпи зростання обсягів зборів (у 2016 р. порівняно 32015 р.) від фізичних осіб - підприємців значно більші ніж від юридичних осіб (табл.5).

Динаміка структури обсягів збору податкових платежів за КВЕД *

Таблиця 5 та видами платників за 2014-2016 рр.*

\begin{tabular}{|c|c|c|c|c|c|c|c|}
\hline \multirow{2}{*}{ Платники податків } & \multicolumn{2}{|c|}{$2014 \mathrm{p}}$. & \multicolumn{2}{|c|}{2015 p. } & \multicolumn{2}{|c|}{2016 p. } & \multirow{2}{*}{$\begin{array}{c}\text { Порівняння } \\
2016 / 2015 \\
\end{array}$} \\
\hline & тис. грн & $\%$ & тис. грн & $\%$ & тис. грн & $\%$ & \\
\hline & \multicolumn{7}{|c|}{ КВЕД 55.20} \\
\hline Юридичні особи & 71632,7 & 82,2 & 77465,1 & 81,6 & 106150,8 & 78,4 & $\uparrow 37 \%$ \\
\hline $\begin{array}{l}\text { Фізичні особи- } \\
\text { підприємці }\end{array}$ & 15511,4 & 17,8 & 17445,1 & 18,4 & 29185,2 & 21,6 & $\uparrow 67,3 \%$ \\
\hline \multirow[t]{2}{*}{ Всього: } & 87144,1 & 100 & 94910,2 & 100 & 135336 & 100 & $\uparrow 42,6 \%$ \\
\hline & \multicolumn{7}{|c|}{ КВЕД 55.30} \\
\hline Юридичні особи & 871,6 & 77,2 & 1035,1 & 88,9 & 1066,5 & 84,1 & $\uparrow 3 \%$ \\
\hline $\begin{array}{l}\text { Фізичні особи- } \\
\text { підприємці }\end{array}$ & 257,5 & 22,8 & 128,9 & 11,1 & 201,8 & 15,9 & $\uparrow 56,6 \%$ \\
\hline \multirow[t]{2}{*}{ Всього: } & 1129,1 & 100 & 1164 & 100 & 1268,3 & 100 & $\uparrow 9 \%$ \\
\hline & \multicolumn{7}{|c|}{ КВЕД 55.90} \\
\hline Юридичні особи & 21453,3 & 84,9 & 20145 & 80,0 & 34201 & 82,2 & $\uparrow 69,8 \%$ \\
\hline
\end{tabular}




\begin{tabular}{|l|c|c|c|c|c|c|c|}
\hline $\begin{array}{l}\text { Фізичні особи- } \\
\text { підприємці }\end{array}$ & 3829,9 & 15,1 & 5047,4 & 20,0 & 7408,3 & 17,8 & $\uparrow 46,8 \%$ \\
\hline Всього: & $\mathbf{2 5 2 8 3 , 2}$ & $\mathbf{1 0 0}$ & $\mathbf{2 5 1 9 2 , 4}$ & $\mathbf{1 0 0}$ & $\mathbf{4 1 6 0 9 , 3}$ & $\mathbf{1 0 0}$ & $\uparrow \mathbf{6 5 , 2} \%$ \\
\hline Разом: & $\mathbf{1 1 3 5 5 6 , 4}$ & $\mathbf{x}$ & $\mathbf{1 2 1 2 6 6 , 6}$ & $\mathbf{x}$ & $\mathbf{1 7 8 2 1 3 , 6}$ & $\mathbf{x}$ & $\uparrow \mathbf{4 6 , 9} \%$ \\
\hline
\end{tabular}

* КВЕД 55.20 «Діяльність засобів розміщування на період відпустки та іншого тимчасового проживання»;

КВЕД 55.30 «Надання місць кемпінгами та стоянками для житлових автофургонів і причепів» КВЕД 55.90 «Діяльність інших засобів тимчасового розміщування».

*Розраховано автором за даними [7]

Проведений аналіз надходжень податкових платежів за 2014-2016 роки суб'єктами туристичного бізнесу показав, що більше $50 \%$ складають надходження від туристичних операторів - юридичних осіб, причому частка надходжень має тенденцію до зростання. В той час, як надходження від турагентів, загалом зменшується, причому від турагентів юридичних осіб зменшується, а турагентів ФОП - зростає (табл.6).

Таблиця 6

Динаміка структури надходження податкових платежів від турагентів та туроператорів 3a 2014-2016 pp.*

\begin{tabular}{|c|c|c|c|c|c|c|c|}
\hline \multirow{2}{*}{$\begin{array}{c}\text { Платники } \\
\text { податків }\end{array}$} & \multicolumn{2}{|c|}{2014 p. } & \multicolumn{2}{|c|}{2015 p. } & \multicolumn{2}{|c|}{2016 p. } & \multirow{2}{*}{$\begin{array}{c}\text { Порівняння } \\
2016 / 2015\end{array}$} \\
\hline & тис. грн & $\%$ & тис. грн & $\%$ & тис. грн & $\%$ & \\
\hline \multicolumn{8}{|c|}{ туристичні агентства } \\
\hline Юридичні особи & 64350,4 & 33,50 & 71179,5 & 31,19 & 80413,7 & 27,29 & $\uparrow 13,0 \%$ \\
\hline Фізичні особи-підприємці & 19170,8 & 9,90 & 23857,6 & 10,45 & 38881,4 & 13,19 & $\uparrow 63,0 \%$ \\
\hline Всього: & 83521,2 & 43,49 & 95037,1 & 41,64 & 119295,1 & 40,49 & $\uparrow \mathbf{2 5 , 5 \%}$ \\
\hline \multicolumn{8}{|c|}{ туристичні оператори } \\
\hline Юридичні особи & 108511,4 & 56,51 & 133171 & 58,36 & 175356,5 & 59,51 & $\uparrow \mathbf{3 1 , 7 \%}$ \\
\hline Разом: & 192032,6 & 100 & 228208,1 & 100 & 294651,6 & 100 & $\uparrow 29,1 \%$ \\
\hline
\end{tabular}

*Розраховано автором за даними [7]

В цілому, податкові надходження від туристичного бізнесу зростають і у 2016 p. порівняно з 2015 р. вони зросли на 29,1\%. Проте надходження можуть бути значно вагомішими, якщо б законодавча податкова база України була стабільною i забезпечувала прибуткову діяльність. В інфраструктурі туризму одне 3 центральних місць займають готелі та аналогічні засоби розміщення. Готельний бізнес є одним 3 важливих елементів сфери послуг, складова частина галузі туризму та джерело валютних надходжень. У 2016 р. в Україні надання місць для проживання здійснювали 4256 колективних засобів розміщування (юридичні особи та фізичні особи-підприємці) із кількістю місць 376 тис. (у 2015p. відповідно 4341 та 404 тис.). Кількість розміщених у них становила 6544,8 тис. осіб, що на 764,9 тис. осіб (13\%) більше, ніж у 2015 p. Серед розміщених осіб $13 \%$ становили іноземці [2]. Аналіз обсягів збору податкових платежів 3 готелів та подібних засобів тимчасового розміщування показав, що у 2016 році порівняно з 2015 роком надходження до бюджету збільшились на 55,7\%. Надходження від юридичних осіб збільшились на $52,9 \%$ та $86,7 \%$ з ФОП (табл.7).

Таблиця 7

Динаміка обсягів збору податкових платежів з готелів та подібних засобів тимчасового розміщування * за 2014-2016 рp., * тис грн

\begin{tabular}{|l|c|c|c|c|}
\hline \multicolumn{1}{|c|}{ Збір податкових платежів } & $\mathbf{2 0 1 4} \mathbf{p .}$ & $\mathbf{2 0 1 5} \mathbf{p .}$ & $\mathbf{2 0 1 6} \mathbf{p .}$ & Порівняння 2016/2015 \\
\hline Юридичні особи & 356574,9 & 583873,2 & 892707,1 & $\uparrow 52,9 \%$ \\
\hline Фізичні особи - підприємці & 38415,0 & 53647,5 & 100179,3 & $\uparrow 86,7 \%$ \\
\hline Всього: & $\mathbf{3 9 4 9 8 9 , 9}$ & $\mathbf{6 3 7 5 2 0 , 7}$ & $\mathbf{9 9 2 8 8 6 , 4}$ & $\uparrow \mathbf{5 5 , 7 \%}$ \\
\hline
\end{tabular}

*КВЕД 55.10 «Діяльність готелів і подібних засобів тимчасового розміщування»

*Розраховано автором за даними [7] 
Слід зазначити, що велике податкове навантаження негативно впливає на розвиток готельного бізнесу в Україні. Для поліпшенням умов роботи ринку готельних послуг у вітчизняну практику доцільно запровадити закордонний досвід, який спрямований насамперед на зниження податків, які повинні сплачувати власники готелів та інших засобів розміщення.

У Європі, наприклад, спостерігається тенденція до зниження податку на додану вартість для готелів. Розмір податку на додану вартість у європейських країнах $\epsilon$ значно нижчим ніж у нашій країні: у Болгарії - 9\%, на Кіпрі - 15\%, в Латвії - 12\%, Німеччині - 7\%, Польщі - 8\%, в Україні - 20\% [1].

Узагальнюючи результати аналізу, слід зазначити, що для того, щоб вклад туристичної галузі у розвиток вітчизняної економіки наблизити до європейських показників, необхідно, щоб однією із стратегічних цілей, як держави, так регіонів, стала туристична привабливість, яка б мала на меті підвищення ефективності використання туристичного потенціалу країни та формування повноцінної туристичної індустрії (рис. 4).

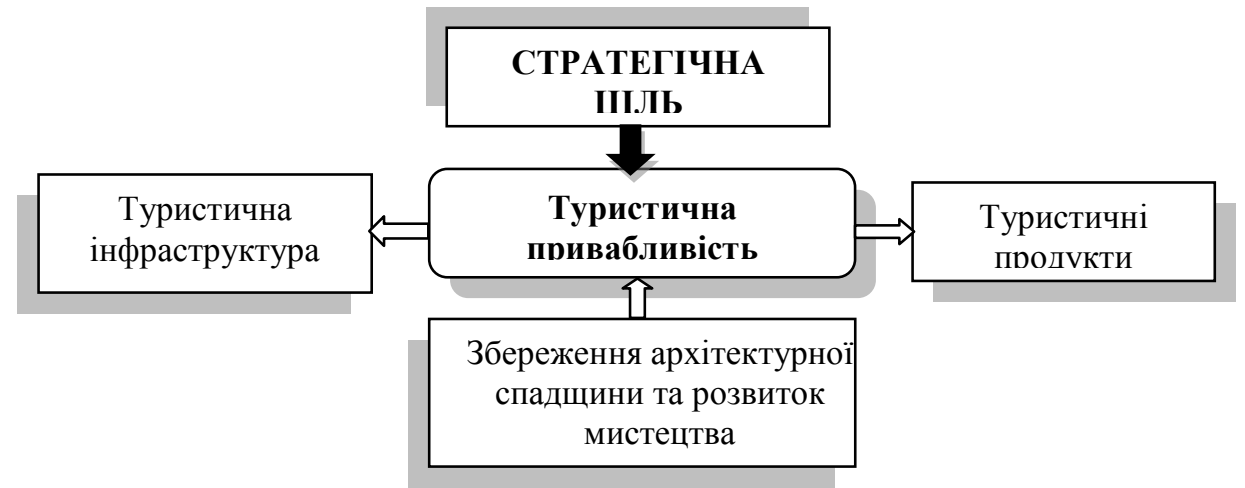

\section{*Розроблено автором}

Рис.4. Модель формування туристичної індустрії *

Для iї реалізації необхідно виконати ряд важливих, на наш погляд, завдань:

- поліпшити транспортну доступність туристичних центрів;

- сприяти розвитку мережі туристичних об'єктів та туристичної інфраструктури;

- ініціювати необхідні зміни у законодавчонормативному забезпеченні;

- формувати та просувати нові туристичні продукти;

- забезпечити проведення масових культурних, ділових, спортивних та туристичних заходів міжнародного й міжрегіонального рівня;

- вдосконалити підготовку професійних кадрів для туристичної галузі;

- розробити та впровадити систему маркетингу туристичного потенціалу;

- розширити мережу туристичних інформаційних центрів;

- забезпечити збереження та раціональне використання цінних рекреаційних ландшафтів, курортних факторів, автентичних екосистем, збереження культурно-історичних пам'яток та ін. Висновки i перспективи подальших досліджень. Аналізуючи діяльність туристичного бізнесу як джерела доходів місцевих бюджетів необхідно зазначити, що його бюджетонаповнююча роль на сьогодні залишається низькою. Однією з причин цього, на наш погляд, $є$ тіньова зайнятість в приватному секторі, велике податкове навантаження, мінливість вітчизняного законодавства та інші об’єктивні фактори.

Проведене дослідження дає підстави стверджувати про позитивну динаміку як відвідувань іноземних туристів України, так i зростання темпів надходжень податкових платежів до бюджету. Причому у структурі надходжень зростає частка платежів від ФОП, у тому числі надходження від ФОП - турагенцій. Збільшенню обсягу надходжень туристичного збору може сприяти i розвиток готельного бізнесу, який $є$ складовою частиною туризму. Проте останні зміни в законодавстві стосовно сплати залежного від доходу суб'єкта господарювання, призвели до закриття бізнесу. Тому туристичноготельному бізнесу як джерелу валютних надходжень, на наш погляд, необхідна державна підтримка та податкове стимулювання розвитку.

Аналізуючи перспективи розвитку туристичного бізнесу в Україні, перш за все необхідно підкреслити, що сучасний туризм - це та сфера економіки i життєдіяльності суспільства, яка має тісні взаємозв'язки практично 3 усіма видами економічної діяльності, підвищує рівень зайнятості, адже 
кожен десятий працівник у світі зайнятий у сфері надання туристичних послуг. I, що найважливіше, розвиток туризму може сприяти зміцненню нового позитивного іміджу України на світовій арені. Подальші дослідження за даною проблематикою можуть бути спрямовані на аналіз податкових надходжень від туристично-готельного бізнесу окремих регіонів (особливо прикордонних) та впливу зміни законодавства на розвиток галузі, вивчення закордонного досвіду податкового стимулювання розвитку туризму.

\section{ПЕРЕЛІК ВИКОРИСТАНИХ ДЖЕРЕЛ}

1. Папп В. В. Роль готельного господарства у розвитку туризму в регіоні. / В.В. Папп // Науковий вісник Ужгородського університету. Серія «Економіка». - Ужгород : 2015. - № (2) 46. - С. 207-212.

2. Офіційний сайт Державного комітету статистики України. [Електронний ресурс]. - Режим доступу http://ukrstat.gov.ua/.

3. Ірина Жук. Туристична реформа як інструмент соціально-економічного розвитку України. Соціальноекономічні проблеми і держава. - Вип. 1 (14). - 2016. - С. 152-159. [Електронний ресурс]. - Режим доступу : http://elartu.tntu.edu.ua.

4. Офіційний сайт Державної прикордонної служби України [Електронний ресурс]. - Режим доступу https ://dpsu.gov.ua/ua/.

5. А.В. Кузишин. Основні показники розвитку туризму в країнах Європейського туристичного регіону на початку XXI століття. Матеріали Міжн. наук.-практ. Інтернет-конф. «Актуальні проблеми країнознавчої науки», Східноєвропейського національного університету імені Лесі Українки. - Луцьк, 2017 [Електронний pecypc]. - Режим доступу : https://internationalconference2014.wordpress.com.

6. Податковий кодекс України від 02.12.2010 p. № 2755-VI.

7. Офіційний сайт Державної фіскальної служби України [Електронний ресурс]. - Режим доступу http ://sfs.gov.ua/.

8. Стратегія розвитку Львівської області на період до 2020 року [Електронний ресурс]. - Режим доступу : https://www.google.com.ua/dfrr.minregion.gov.ua.

9. Закон України «Про туризм» від 15.09. 1995 р. № 325/95-ВР.

\section{REFERENCES}

1. Papp, V.V. (2015). Rol' hotel'noho hospodarstva u rozvytku turyzmu v rehioni [The role of the hotel industry in region tourism development]. Naukovyy visnyk Uzhhorods'koho universytetu. Seriya «Ekonomika». - Scientific Bulletin of Uzhgorod University. The series "Economics", (2) 46, 207-212 [in Ukrainian].

2. Ofitsiynyy sayt Derzhavnoho komitetu statystyky Ukrayiny [Official site of the State Statistics Committee of Ukraine], http://ukrstat.gov.ua/. Retrieved from: http://ukrstat.gov.ua/ [in Ukrainian].

3. Zhu, I. (2016). Turystychna reforma yak instrument sotsial'no-ekonomichnoho rozvytku Ukrayiny [Tourist reform as an instrument of socio-economic development of Ukraine]. Sotsial'no-ekonomichni problemy i derzhava Socio-economic problems and the state, 1 (14), 152-159. Retrieved from:: http://elartu.tntu.edu.ua. [in Ukrainian].

4. Ofitsiynyy sayt Derzhavnoyi prykordonnoyi sluzhby Ukrayiny [Official site of the State Border Guard Service of Ukraine]. https ://dpsu.gov.ua. Retrieved from: https ://dpsu.gov.ua/ua/ [in Ukrainian].

5. Kuzyshyn, A.V. (2017). Osnovni pokaznyky rozvytku turyzmu v krayinakh Yevropeys'koho turystychnoho rehionu na pochatku XXI stolittya [The main indicators of tourism development in the countries of the European tourist region at the beginning of the XXI century]. Proceedings from^ ${ }^{\wedge}$ Materialy Mizhn. nauk.-prakt. Internet-konf. «Aktual'ni problemy krayinoznavchoyi nauky», Skhidnoyevropeys'koho natsional'noho universytetu imeni Lesi Ukrayinky. Retrieved from: https://internationalconference2014.wordpress.com [in Ukrainian].

6. Podatkovyy kodeks Ukrayiny vid 02.12.2010, № 2755-VI. [The Tax Code of Ukraine from December 02, 2010, № 2755-VI] [in Ukrainian].

7. Ofitsiynyy sayt Derzhavnoyi fiskal'noyi sluzhby Ukrayiny [Official website of the State Fiscal Service of Ukraine]. http://sfs.gov.ua/. Retrieved from: http://sfs.gov.ua/ [in Ukrainian].

8. Stratehiya rozvytku L'vivs'koyi oblasti na period do 2020 roku [Development Strategy of the Lviv region for the period up to 2020]. https://www.google.com.ua/dfrr.minregion.gov.ua. Retrieved from: https://www.google.com.ua/dfrr.minregion.gov.ua. [in Ukrainian].

9. Zakon Ukrayiny «Pro turyzm» vid 15.09. 1995 r. № 325/95-VR [The Law of Ukraine "On Tourism" from September, 15, 1995, № 325/95-VR]. [in Ukrainian].

Одержано 12.03. 2018 р. 